\title{
Front Matter: Volume 8034
}

, "Front Matter: Volume 8034," Proc. SPIE 8034, Photonic Microdevices/ Microstructures for Sensing III, 803401 (6 July 2011); doi: 10.1117/12.900054

SPIE Event: SPIE Defense, Security, and Sensing, 2011, Orlando, Florida, United SPIE. States 


\title{
PROCEEDINGS OF SPIE
}

\section{Photonic Microdevices/ Microstructures for Sensing III}

\author{
Hai Xiao \\ Xudong Fan \\ Anbo Wang \\ Editors
}

27-28 April 2011

Orlando, Florida, United States

Sponsored and Published by

SPIE 
The papers included in this volume were part of the technical conference cited on the cover and title page. Papers were selected and subject to review by the editors and conference program committee. Some conference presentations may not be available for publication. The papers published in these proceedings reflect the work and thoughts of the authors and are published herein as submitted. The publisher is not responsible for the validity of the information or for any outcomes resulting from reliance thereon.

Please use the following format to cite material from this book:

Author(s), "Title of Paper," in Photonic Microdevices/Microstructures for Sensing III, edited by Hai Xiao, Xudong Fan, Anbo Wang, Proceedings of SPIE Vol. 8034 (SPIE, Bellingham, WA, 2011) Article CID Number.

ISSN 0277-786X

ISBN 9780819486080

Published by

SPIE

P.O. Box 10, Bellingham, Washington 98227-0010 USA

Telephone +1 3606763290 (Pacific Time) · Fax +1 3606471445

SPIE.org

Copyright (C) 2011, Society of Photo-Optical Instrumentation Engineers

Copying of material in this book for internal or personal use, or for the internal or personal use of specific clients, beyond the fair use provisions granted by the U.S. Copyright Law is authorized by SPIE subject to payment of copying fees. The Transactional Reporting Service base fee for this volume is $\$ 18.00$ per article (or portion thereof), which should be paid directly to the Copyright Clearance Center (CCC), 222 Rosewood Drive, Danvers, MA 01923. Payment may also be made electronically through CCC Online at copyright.com. Other copying for republication, resale, advertising or promotion, or any form of systematic or multiple reproduction of any material in this book is prohibited except with permission in writing from the publisher. The CCC fee code is 0277-786X/11/ \$18.00.

Printed in the United States of America.

Publication of record for individual papers is online in the SPIE Digital Library.

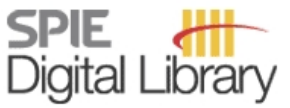

SPIEDigitalLibrary.org

Paper Numbering: Proceedings of SPIE follow an e-First publication model, with papers published first online and then in print and on CD-ROM. Papers are published as they are submitted and meet publication criteria. A unique, consistent, permanent citation identifier (CID) number is assigned to each article at the time of the first publication. Utilization of CIDs allows articles to be fully citable as soon as they are published online, and connects the same identifier to all online, print, and electronic versions of the publication. SPIE uses a six-digit CID article numbering system in which:

- The first four digits correspond to the SPIE volume number.

- The last two digits indicate publication order within the volume using a Base 36 numbering system employing both numerals and letters. These two-number sets start with 00, 01, 02, 03, 04, $05,06,07,08,09,0 A, 0 B \ldots 0 Z$, followed by 10-1Z, 20-2Z, etc.

The CID number appears on each page of the manuscript. The complete citation is used on the first page, and an abbreviated version on subsequent pages. Numbers in the index correspond to the last two digits of the six-digit CID number. 


\section{Contents}

vii Conference Committee

\section{SESSION 1 MICROPHOTONIC BIOSENSORS}

803402 Photonic crystal microarray nanoplatform for high throughput detection of biomolecules [8034-01]

S. Chakravarty, Omega Optics, Inc. (United States); W.-C. Lai, K. Moncivais, The Univ. of Texas at Austin (United States); X. Wang, Omega Optics, Inc. (United States); C.-Y. Lin, Z. J. Zhang, R. T. Chen, The Univ. of Texas at Austin (United States)

803403 Identification of biological agents using surface enhanced Raman scattering (Invited Paper) [8034-02]

T. L. Paxon, R. S. Duthie, C. Renko, A. A. Burns, GE Global Research (United States);

M. L. Lesaicherre, Morpho Detection Inc. (United States); F. J. Mondello, GE Global Research (United States)

803404 A new generation of mid-infrared sensors based on quantum cascade laser (Invited Paper) [8034-03]

D. Dey, J. Kohoutek, R. M. Gelfand, A. Bonakder, H. Mohseni, Northwestern Univ. (United States)

803405 Immobilization of aptamers onto unmodified glass surfaces for affordable biosensors [8034-04]

R. Chen, C. Surman, R. Potyrailo, A. Pris, GE Global Research (United States); E. A. Holwitt, V. K. Sorola, J. L. Kiel, Air Force Research Lab. (United States)

803406 Integrated photonic structures for parallel fluorescence and refractive index biosensing [8034-05]

M. M. Lee, T. D. O'Sullivan, A. Cerruto, V. Liu, Stanford Univ. (United States); J. Zhang, The Univ. of New Mexico (United States); O. Levi, Univ. of Toronto (Canada); H. Lee, Korea Univ. (Korea, Republic of); S. R. J. Brueck, The Univ. of New Mexico (United States); S. Fan,

J. S. Harris, Stanford Univ. (United States)

\section{SESSION 2 NEW AND ENABLING MICROPHOTONIC DEVICES AND SENSORS I}

803407 Beating the diffraction limit using a 3D nanowires metamaterials nanolens (Invited Paper) [8034-18]

B. D. F. Casse, Y. J. Huang, W. T. Lu, E. Gultepe, L. Menon, S. Sridhar, Northeastern Univ. (United States)

803409 Thinned fiber Bragg grating magnetic field sensor with magnetic fluid [8034-08]

C. Zhou, Wuhan Univ. of Technology (China) and Univ. of Toronto (Canada); L. Ding,

D. Wang, Y. Kuang, D. Jiang, Wuhan Univ. of Technology (China) 
8034 OA Passive infrared sensing using plasmonic resonant dust particles [8034-10] M. Mirotznik, Univ. of Delaware (United States); W. Beck, K. Olver, J. Little, U.S. Army Research Lab. (United States)

8034 OD Ultra-fast and ultra-sensitive 2,4-dinitrotoluene vapor sensing using gold nanoparticle assembled SERS probes [8034-13]

M. K. Khaing Oo, C.-F. Chang, Y. Sun, X. Fan, Univ. of Michigan (United States)

\section{SESSION 4 NEW AND ENABLING MICROPHOTONIC DEVICES AND SENSORS II}

8034 OF Fully distributed fiber-optic sensing based on acoustically induced long-period grating (Invited Paper) [8034-15]

D. Y. Wang, Y. Wang, M. Han, J. Gong, A. Wang, Virginia Polytechnic Institute and State Univ. (United States)

8034 OG Polarimetric heterodyning fiber grating laser sensors (Invited Paper) [8034-16] B.-O. Guan, Jinan Univ. (China); Y. Zhang, Y.-N. Tan, PolyU-DUT Joint Research Ctr. For Photonics, Dalian Univ. of Technology (China); T. Guo, Jinan Univ. (China); H.-Y. Tam, The Hong Kong Polytechnic Univ. (Hong Kong, China)

$8034 \mathrm{OH} \quad$ U-shaped nano-apertures for enhanced optical transmission and resolution [8034-17] M. Turkmen, Erciyes Univ. (Turkey) and Boston Univ. (United States); S. Aksu, A. E. Çetin, A. A. Yanik, A. Artar, H. Altug, Boston Univ. (United States)

\section{SESSION 5 NEW AND ENABLING MICROPHOTONIC DEVICES AND SENSORS III}

8034 Ol Fiber-optic intrinsic Fabry-Perot interferometric sensors fabricated by femtosecond lasers (Invited Paper) [8034-06]

T. Wang, Shanghai Univ. (China); W. Wang, Shanghai Univ. (China) and Hebei United Univ. (China); N. Chen, F. Pang, Shanghai Univ. (China)

8034 OJ High-sensitivity temperature sensing by employing an on-chip high-Q PDMS-coated toroidal microcavity [8034-19]

B.-B. Li, Q.-Y. Wang, X.-F. Jiang, Q. Gong, Y.-F. Xiao, Peking Univ. (China)

8034 OK Resonant cavity enhancement of polycrystalline PbTe films for IR detectors on Si-ROICs [8034-20]

J. Wang, T. Zens, J. Hu, P. Becla, A. M. Agarwal, L. C. Kimerling, Massachusetts Institute of Technology (United States)

$8034 \mathrm{OL} \quad$ Frequency-tunable nonlinear-optical negative-index metamirror for sensing applications [8034-21]

A. K. Popov, Univ. of Wisconsin-Stevens Point (United States)

8034 OM Sapphire tube waveguide as a potential basis for high-temperature Raman spectroscopy [8034-23]

M. Fraser, E. Lally, A. Wang, Virginia Polytechnic Institute and State Univ. (United States) 
POSTER SESSION

8034 ON Fiber Bragg grating high-current sensor based on magnetic coupling [8034-22]

C. Zhou, Wuhan Univ. of Technology (China) and Univ. of Toronto (Canada); D. Wang, W. Zhang, L. WU, Y. Yao, Wuhan Univ. of Technology (China)

Author Index 
Downloaded From: https://www.spiedigitallibrary.org/conference-proceedings-of-spie on 26 Apr 2023

Terms of Use: https://www.spiedigitallibrary.org/terms-of-use 


\title{
Conference Committee
}

\author{
Symposium Chair
}

William Jeffrey, HRL Laboratories, LLC (United States)

Symposium Cochair

Kevin P. Meiners, Office of the Secretary of Defense (United States)

Conference Chairs

Hai Xiao, Missouri University of Science and Technology (United States)

Xudong Fan, University of Michigan (United States)

Anbo Wang, Virginia Polytechnic Institute and State University (United States)

Program Committee

Hatice Altug, Boston University (United States)

Junhang Dong, University of Cincinnati (United States)

Henry H. Du, Stevens Institute of Technology (United States)

Erica Forzani, Arizona State University (United States)

Bai-Ou Guan, Jinan University (China)

Susan M. Maley, U.S. Dept. of Energy (United States)

Radislav A. Potyrailo, GE Global Research (United States)

Venkataraman S. Swaminathan, U.S. Army Armament Research,

Development and Engineering Ctr. (United States)

Wei Jin, The Hong Kong Polytechnic University (Hong Kong, China)

Ian M. White, University of Maryland, College Park (United States)

Yibing Zhang, ExxonMobil Research and Engineering Co. (United States)

Mohammed M. Zourob, Biophage Pharma Inc. (Canada)

Session Chairs

1 Microphotonic Biosensors

Xudong Fan, University of Michigan (United States)

Hai Xiao, Missouri University of Science and Technology (United States)

2 New and Enabling Microphotonic Devices and Sensors I

Bai-Ou Guan, Jinan University (China) 
3 Microphotonic Chemical Sensors

Hai Xiao, Missouri University of Science and Technology (United States)

Xudong Fan, University of Michigan (United States)

$4 \quad$ New and Enabling Microphotonic Devices and Sensors II

Xudong Fan, University of Michigan (United States)

Hai Xiao, Missouri University of Science and Technology (United States)

$5 \quad$ New and Enabling Microphotonic Devices and Sensors III

Bai-Ou Guan, Jinan University (China)

Dorothy Y. Wang, Virginia Polytechnic Institute and State University (United States) 